\title{
PJTV as a Sunda Cultural Socialization Media
}

\author{
Itsna Nurhayat $\mathbf{E}^{\mathbf{1}}$, Muhammad Tanziil $\mathbf{S}^{\mathbf{2}}$ \\ Universitas Muhammadiyah Sukabumi, Indonesia \\ itsna.aqila@gmail.com,tanzilsuherman@ummi.ac.id
}

\section{Abstract}

This research aims to find out how PJTV as one of the local televisions in Bandung socializes Sundanesse culture through television media, and also to determine the factors that support and hinder PJTV in socializing Sundanese culture as an effort to preserve it. The research method used is descriptive qualitative method. Sampling was done by purposive sampling, namely selecting certain people who are considered important and representative. This research uses a structural functional approach by Talcott Parsons which states that in explaining functional structural existence it can be observed from the existence of individuals who are integrated in a system, and this condition occurs from functional and structural relationships and is supported by the existence of socializatiuon and social control mechanisms that run constantly.
Keywords

functional structural; socialization; culture

\section{Introduction}

The emergence of television media in human life presents a civilization, especially in the process of mass communication and information. The globalization of information and communication in every mass media clearly produces social effects that are charged with changing human social and cultural values. Television as a medium that emerged later than print and radio media, turned out to provide a very spectacular value in terms of the social interactions of human life today. Television media eventually gave birth to a new term in the pattern of human civilization, better known as "mass culture (human culture). Humans tend to become consumers of mass culture through "magic boxes" that produce sound and images. Individuals are also exposed to social realities that are broadcast in the mass media. Today's television broadcast can be done anywhere. The attraction of television media is so great that the patterns of human routine life before television appear have changed completely. Television media has become a new role model for human life, so that in the end, television media has become a tool or means for the purpose of human life, both for political and commercial interests, and even the order of human cultural values that has existed for a long time.

Television media as one of the pioneers in disseminating information continues to grow rapidly. Today, television can be said to be able to occupy attention and dominate almost everyone's time, with a value more than the combination of functionsaudio(sound) and visuals (images), coupled with the ability to play colors, make it easier for viewers to understand the information displayed, and freely determine which channels they enjoy doing. Television is needed as a discourse for media information, education, entertainment and business. 
Currently, private television in Indonesia is pursuing music program packages, films, talk shows, reality shows, mysteries, films and soap operas. The emergence of private television in Indonesia led to the birth of a new tradition in people's life patterns. The emergence of private television media in human life, presents a process of communication and information that is mass in nature, so that even a region tries to create something that can bring appropriate information to its people, by forming regional local television. One of them is Parijz van java Televisi or abbreviated as PJTV.

Talking about cultural values, we cannot be separated from the understanding of culture itself. According to EB Taylor in his book Primitive Culture, culture is a complex that includes knowledge, beliefs, arts, morals, laws, customs and abilities and habits acquired by humans. This statement implies that culture includes everything that humans get or learn as members of society. Culture consists of everything that is learned from normative patterns of behavior, that is, it includes all ways or patterns of thinking, feeling, and acting. Defa (2020) stated that the role of a positive culture is as a barrier to each individual to implement the prevailing norms in the community. The role of culture is very important for human life with the rules.

According to Selo Soemarjan and Soelaeman Soemardi in their book Communication and Community Development, they define culture as all the work, taste and creation of society. Community work produces technoogi and material culture or physical culture, which is needed by humans to master the surrounding nature, so that the provisions and results can be perpetuated for the community. In terms of maintaining a cultural value, West Javanese who have creative ideas, try to create local TV, with the goal is to maintain the cultural values that are still there, namely by making and arranging programs of which approximately $70 \%$ contains Sundanese culture.

Parijz van java television or PJTV is one of the electronic communication media which is Audio visual. PJTV broadcasts can be received by the people of Bandung City, Cianjur Regency, Sumedang Regency, Majalengka Regency, and Kuningan Regency. This assumption begins with the main function of mass media according to Infante (1990: 347348), Five functions of mass communication: Surveillance, Correction, Transmission, Entertainment, and Mobilitation. The function of PJTV in this case cannot be separated from the five functions of the media. The broadcast on PJTV also functions as a medium of entertainment (entertainment) and increases knowledge.

PJTV started broadcasting on January 1, 2015, and is currently operating with broadcast hours of 19 hours per day, starting from 05.00-00.00 WIB. According to the demands of the world BroadcastingPJTV also has professional staff, most of whom are Diploma and College graduates, and some are journalists who have long been involved in the world of print and journalism. In terms of management, PJTV has information capable of accommodating and handling various departments in their operational activities, among others; news / editorial department, events program department, finance department, general department, administration, human resources and marketing and promotion department. All of these departments are interrelated with each other, with the aim of forming a regional TV, namely PJTV as a local TV which is full of cultural information, especially Sundanese culture.

As a television base that carries the name "PJTV, Jabar pisan euyy", PJTV strives to become an institution that is a place for the socialization of cultural values, so that the people of West Java are always expected to maintain these cultural values, even though in the form of local television which was created as a means of cultural transformation, especially West Java, whose majority of people are Sundanese, by seeing what programs are offered in order to maintain existing cultural values. Television as an information 
medium must be selective in translating the term globalization and information contained in the program packages offered.

Researchers here are trying to find out how PJTV, as a medium for socializing cultural values and at the same time as a window for the dissemination of cultural information for the people of West Java, in the effort and creativity to maintain Sundanese cultural values in the form of television mass media, so that PJTV has an important meaning and is able to become a local television that carries cultural elements, namely Sundanese culture. How is the socialization process carried out by PJTV, as well as what factors support and what factors hinder the socialization of Sundanese culture carried out by PJTV.

\section{Review of Literatures}

\subsection{Functional Structural Approach}

Theory theorycultural-functional observes the form of structure and function in a society, so that it can see how a society changes or is established through each interrelated and dynamic element to fulfill individuals and groups. Basically, the assumption of structural-functional theory is that society is a system consisting of parts (sub-systems) which are interconnected with one another (Nasikun: 1996: 10). The theoretical approach which can include all elements in all theories is sociological theory which explains the various institutionalized activities in relation to the "needs" of society (Merton, 1975: 82). The "need" referred to, when connected with media institutions, is particularly concerned with sustainability, order, integration, motivation, direction (guidance) and adaptation. Society is seen as a system consisting of several interrelated parts or sub-systems. Each sub-system has a significant role, and one of the many sub-systems is the media.

An orderly social life requires the care of all parts of society and the social environment carefully and continuously. In other words, the media is expected to be something that can respond to new possibilities based on actual reality. The social system is a concrete illustration in explaining the position and role of the structural-functional approach. Because the social system is a structure or part that is interconnected and has a reciprocal role.

Talcott Parsons is one of the figures of the structural-functional approach, saying that in explaining the structural-functional existence it can be observed from the existence of individuals who are integrated in a system, and this condition occurs from functional and structural relationships and is supported by the existence of socialization and social control mechanisms that are running constantly. This can be interpreted that in observing social phenomena, structural-functional observation is focused on two aspects, namely internally (subjective) and externally (objectively), both of which are united in a broad system meaning.

Some of the basic assumptions of the media in relation to structural functional theoretical frameworks are as follows:

a. Media institutions carry out the production, reproduction and distribution of knowledge in the sense of a series of symbols that contain meaningful references to experiences in social life.

b. The mass media has a mediating role between objective social reality and personal experience. Mass media is often outside our perception and direct contact, where the mass media can be between us and other institutions that are related to our activities, law, government industry, and others; mass media can provide a conduit for different institutions; the media also channels other parties to contact us (Ashadi, in Rahayu, 76: 2000) 


\subsection{Socialization Process}

According to the Psychology dictionary (Chaplin, 1975: 470) socialization is defined as the process of studying the customs, habits, ways of life of the people, and the customs of a certain culture. Hurlock, (1974), defines socialization as a learning process to conform with standards, values, and habits, learning to behave in accordance with social rewards. Meanwhile, Shibutani (Koeswara, 1988:57), briefly suggests socialization as a process by which newcomers learn to participate effectively in social groups.

As expressed by Talcott Parsons (Johnson; 1992: 122), that through the process of socialization, humans internalize the values in society, that is, humans make the social values of the cultural system their own by learning from other actors; then learn the role of what should be implemented (role expectation) so that humans participate in society. In line with that, Krech (1962: 318), argues that in dealing with common problems, community members employ various ways of solving them, one of which is explicitly defined and conveyed or disseminated to subsequent generations as the culture of society.

\subsection{The Role of Television}

The flow of information is increasingly developing, it can no longer be limited by space or time, as well as the information technology and communication technology that accompanies it. Hence it changes soUnfortunately, the world community is also running very fast, as expressed by William Paisley (1985: 23), namely the change in technology places communication at the forefront of the social revolution. The emergence of television media as a long-distance human communication tool indicates that the world of mass communication technology provides a social phenomenon in human life. It can be clearly seen that the role of television media for human communication channels characterizes that the process of human interaction is important for society to increase knowledge of developing information. In addition, the level of interests and needs of the community is met in a clear and directed manner.

In the end, the basic ideas regarding the role and purpose of television media present in society are as follows:

1. Information

- Provides information about events and conditions in society and the world

- Shows power relations

- Facilitate innovation, adaptation and progress

2. Correlation

- Explaining, interpreting, commenting on the meaning of information events

- Supporting authority on behalf of established norms

- Socializing

- Form an agreement

- Specifies the order of priority and assigns a relative status

3. Continuity

- Expresses dominant culture and acknowledges the existence of a special culture and the development of new cultures

- Increase and preserve values

4. Entertainment

- Provides entertainment, diversion, and a means of relaxation

- Relieves social tension

5. Mobilization

- Campaigning for the goals of society in politics, war, economic development, employment, and sometimes also in the field of religion (Wright, in McQuil, 1994: 70-71) 


\subsection{Concept of Culture and Cultural Socialization}

Culture is a form of human creativity, initiative and taste. As an ethnic group that has a long history, Sundanese culture has a very rich culture, which is the manifestation of human creativity in the form of objects created by humans. The form of human sense power is in the form of patterned behavioral activities of humans in society, while the form of human initiative is a complex of ideas, ideas, values, norms, rules and so on, including character and thinking patterns.

According to Kurt Lewin, (in Mc Quaill, 1994: 221), television is part of a culture, if you view the mass media as part of a wider observer's effort process, in this case television is created as an attempt to regulate other communication behavior towards living space. and the environment. In other words, the media as an object is applied in a sobad luck from a preexisting environment. The cultural approach seeks to explain how mass culture plays a role in integrating and overthrowing groups of people who then deviate and oppose, while the socio-cultural approach seeks to explore messages and the public, through careful, critical and directed social understanding of various small groups of society, with the aim of being able to provide explanations concerns patterns of choice and reaction to the media.

According to Charlotte Buehler, socialization is a process that helps individuals, through learning and adjusting, how to live and how to think groups, in order to play a role and function in life (1972: 12). This process can run harmoniously, and it can also occur through conflict, but as long as individuals feel they need the group, people are willing to make some compromises to cultural demands.

Cultural socialization according to Hussein Ismail is a process in which culture is made as something that is considered important to be applied in this life, culture in this case is considered as a form, process and result of human responses to their lives, environment, habits, traditions, customs, values and norms together, so as to influence the behavior and results of community activities, which can explain a whole way of life, so that people live according to existing rules, so that culture needs to be socialized (1996:27).

The process of socialization occurs through social interactions, namely relationships between humans that produce an influence-influence process. In social interactions and contacts between ethnicities, all communities should not develop negative prejudice against one another. In social interactions, ethnic and tribal attitudes should be aware of socio-cultural values by cross-cultural and cross-ethnic activities (Napitu et al, 2020). In the process of human maturation based on their own experience, a behavior system will always be formed which is also determined by the personal character of each individual, namely how the individual will react to an experience, in the end this behavior system will determine and shape the attitude against culture) (Buehler: 1972: 13). Because society consists of individuals who interact with each other, it automatically changes society. So that social processes can be defined as changes in the structure of society as a result of communication and efforts to influence individuals in a culture. In addition, because the individual unconsciously while adjusting also changes indirectly (together with other individuals) and society.

Through social and socialization processes, a culture can be raised and formed in the community. Social groups are known as groups, with the characteristics of "an organization of two or more individuals in role structure adapted to the performance. af a particular function "(1963: 112). One form of the group is the media, for example television. Television is present in society as a form of information that comes from the human mind which is aware of human interdependence with each other to keep getting information. 
As the formation of a culture, television also tries to become a place or socialization through interaction and social processes. Likewise, the formation of television occurs through the process of interaction between life in society, as a dramatic form of life played on the screen. The process of forming television in society occurs through communication, because communication is a process of interaction with a stimulus that acquires a certain meaning, is answered by others (response) verbally, in writing or not, communication produces social interaction, which allows social contact, where contact social is the first effort or action, but it does not mean that a continuous communication is formed,

\section{Research Methods}

This research uses a qualitative approach with descriptive methods. The qualitative approach used in this study is naturalistic, which assumes that the behavior and meaning of a group of humans can only be understood through analysis of their natural environment. The data collection technique used was to conduct interviews with informants. To complement the data, researchers also made observations and use of documents on matters relating to research problems.

\section{Results and Discussion}

Culture as something real (habits and behavior), views culture as coming from the same response to natural realities, and events that collectively become habits or traditions. This tradition is of course a good tradition, valuable, high value then becomes value. The ideal values then become things that are deemed worthy, glorified into norms, which are expected to become ideals that regulate people's behavior.

PJTV tries to raise cultural values as part of the cultural system, namely those concerning aspects of ideas. The aspect of the idea here is that PJTV seeks to create media as a place to socialize in working to build Bandung as a city with a Sundanese culture. In the further development of PJTV, everything is inseparable from the idea of Bandung as a cultural center, especially Sundanese culture. In this case there are three definitions built by PJTV. First, positively trying to build Bandung as a physical center of Sundanese culture that exists and develops into a reference for people with Sundanese culture. Second, by developing superior creativity it can contribute to world civilization. A very important contribution to world civilization, namely the Sundanese language. Third, the center of Sundanese culture from the leadership aspect.

When linked with the structural_functional theory, basically this theory does not consider the need for a change in ideology for the media, because the media are essentially capable of directing and correcting themselves, in accordance with politically agreed regulations. In this case, PJTV is a sub-system that has a meaningful role in people's lives. An orderly social life certainly requires careful and sustainable maintenance of all parts of society and the social environment.

For a meaning of a cultural value system, PJTV as a place for cultural socialization is a form (structure) and Sundanese culture, in this case Sundanese language is a system of functions in a cultural form, one of which regulates life in the community. Society and this value system cannot be separated, because both society and the value system are complementary in their life processes. According to George Ritzer (1992: 25) states that in structural-functional theory, organization is a social system consisting of parts or elements that are interrelated and unite in a process of balance. The basic assumption of Ritzer is that in every structure in the social system, there is a functional network inside. 
In a functional network, it is always necessary to have a good strategy to create a good system consisting of parts that are interconnected with one another. The main strategy carried out by PJTV is to expand the network to all areas of Bandung and cities in West Java in general. And in a constructive strategy, the strategy currently carried out by PJTV is to prioritize Sundanese culture, in this case especially Sundanese.

The strategy developed by PJTV is to offer program packages that are deliberately made to be presented to viewers, the programs that are presented on average reflect the values of cultural traditions, and in making program packages, Sundanese cultural observers are also consulted. The message conveyed in each program always represents the actuality of people's life in social reality. The strategies carried out by PJTV in the future are to create a strategy as a way to "bigger local media", therefore PJTV is trying to become a place of socialization for the community to highlight the meaning of Sundanese culture, especially Sundanese which is now becoming rare used.

Talking about a cultural concept in various kinds of television shows that are always present in front of viewers presenting various programs and special information. This will reflect the concept of acting in accordance with the wishes derived from the information on television shows. As for the creation of your televisioncal as a socialization medium, the cultural concepts used by PJTV include oral and written culture, all of which are applied in broadcast material. These two concepts were able to create PJTV as a television medium and become a tool or means to achieve the goals of human life, so that PJTV eventually gave birth to a new term in the pattern of human civilization which is better known as "Mass Culture". Humans tend to become consumers of mass culture through magic boxes (television) that produce sound and images. Individuals are also exposed to social realities broadcast on the mass media.

In this case, the media as a container of information tries to be a place or socialization to confirm and teach something new culture. And as humans who need information, we certainly still remember that in the early days of every mass media, socialization wasthe most important function. Because basically, socialization is created first of all from a socio-cultural process which is a process, in which the process leads to a socialization process. PJTV acts as a place of socialization in advancing the Sundanese language.

Media as a channel for culture or information. This information emphasizes the quality of culture that really belongs to the nationality. Advances in technology, especially television media have acquired an image as something new and need to be noticed and followed by the program material. Television as an information medium must be selective in translating the terms globalization and information in the packages that will be presented to viewers. Basically, the function of language on television is divided into four types, namely first, language functions as a means of social control, namely the expression of subtle language styles to insinuate or criticize a social gap that occurs in society. Second, language functions as a means of self-expression, where viewers can learn how to follow and use the language. Third, language serves as a promotional tool. And fourth, language functions as a means of integration and adaptation, namely the role of television media in its program packages must use language that can clearly inform what events are happening in society.

Of the four language functions above, one thing that television planners need to know is how to make television program packages with language and images that are communicative, informative, and effective in conveying the contents of the program's message to viewers, regardless of whether it aims to influence the viewer's attitude or not. 


\subsection{The Socialization Process That PJTV as Local TV in the Socialization of Sundanese Culture}

The process of cultural socialization is a process, which means that culture is a symptom of change, a symptom of adjustment and a symptom of formation. All these symptoms are caused by culture being able to adapt in individuals to one another and adapt to circumstances. This effort will continue to be carried out by everyone as long as the culture is valuable, as long as it is felt that at any time there is progress, therefore this process leads to a process of socialization. Robert Edwad Turner, the founder and owner of the CNN network, once argued that the first socialization undertaken on television was when broadcasting programs that presented social realities so that they provided spectacular value in the social aspects of human life.

PJTV in its socialization process views local traditions (community cultural identities) such as courtesy, respecting parents, upholding regional languages, preserving regional dances that are beginning to be eroded by western culture as one way to create critical and innovative thinking in shaping media. In this case, there are three forms of variables that must be carried by PJTV to the people of Bandung and its surroundings, and social changes, namely, first, program programs and broadcast times, secondly, cultural attitudes and behaviors of the community and third, is to continue to preserve Sundanese cultural products There are, other than Sundanese language which is seen as a form of Sundanese culture, which must be maintained. The three variables are related to one another.

In a development, the socialization process occurs through social interaction, namely relationships between humans that produce a process of influencing influence. In the process of human maturation based on their own experiences, a system of behavior will always be formed which is also determined by the personal character of each individual, namely how the individual will react to an experience, finally this behavior system will determine and shape it.

And of course, the media played a role in the early socialization of children and the socialization of adults in the long term being widely accepted, although in essence it is almost impossible to prove. This is because the media is such a long process, and partly because of the impact of media interactions with the influence of other social backgrounds and variations in socialization within the family. However, certain basic assumptions about the potential socialization impact of the media appear in media control policies, namely the decisions made by the media themselves, as well as the norms and expectations that everyone shares when watching the television media they watch.

Parsons makes a theoretical approach to explain socialization, the theory is the Passive Theory Of Sosialization, which places the value of socialization in a one-way process. Such as the existence of PJTV which modernizes the values and cultural norms that have been there before to the community through its programs. In this case, PJTV accepts and re-studies Sundanese cultures that exist indirectly, this takes place in a structured manner so that a value for the institution is formed through the programs it broadcasts. If you look at the example above, this is what Parsons calls the Basic Personality Structure, and for each individual in PJTV,

PJTV defines socialization as an effort to socialize Sundanese culture programs (programs) in the midst of society, assuming that the influence of television programs is still relatively strong when compared to radio and newspapers. This happens because the audiovisual power of television touches the psychological aspects of viewers. Regardless of the positive or negative influences, in essence the television media has become a 
reflection of the viewing culture for viewers in today's rapidly growing information and communication era.

As expressed by Talcott Parsons (Johnsos, 1992: 122), that through the process of socialization, humans internalize values in society, in the sense that humans make social values from the cultural system their own by learning from other actors. They learn the role of what should be carried out (Role Expectation) so that he participates in society. From that view, it appears that a socialization is created for the good of humans in this life. And socialization is an effort to teach norms and values through symbolic praise and punishment for various types of behavior.

Information has become a major human need to achievedestination. Through information, humans can find out about events that occur around them, broaden their horizons of knowledge, as well as understand their position and role in society. Indonesia is known for its traditional values and culture of manners, this will obviously help answer the influence of television on the attitudes and behavior of viewers who consist of various social layers.

The screening of foreign films on television is considered as entertainment, but because the contents are not in accordance with the national social and cultural realities, PJTV makes a program plan based on literature and cultural findings in the community. In designing or making a cultural program package, it is not something that is easy or easy, because the thing that is worrying about television program packages is the impact of viewers' attitudes which tend to be negative and out of social reality because they want to identify with the television media show. However, in creating information sources and transforming them into a program package, PJTV tries to make the best and most useful program package for the media and its audience.

\subsection{Supporting and Inhibiting Factors}

The existence of television as a broadcasting medium cannot be separated from society because the two are interrelated in the interests of the integration system and the pattern (institutional) system of socio-cultural development. PJTV is said to be a structured organization, where PJTV is also a place for the socialization process, because PJTV is forward and explicitly shows that every message conveyed has a target audience and will result in feedback, either directly or indirectly to the people of Bandung City. in particular, and cities in West Java in general as the audience.

Messageyes, the advancement of telecommunications, media and informatics, as well as the rapid development of information technology, has opened up opportunities for the access, management and utilization of large amounts of information quickly and accurately. The fact shows that the use of telematics technology is a very important factor in various accesses both nationally and internationally. The supporting factors of a television progress really depend on the existence of each individual to manage and operate the television properly. Motivation for everyone in television is very much needed, because if they don't have motivation, then what they expect for the good of the media they hold will not be achieved.

Besides that faSupporting actors are also determined by how the presence of television is for the audience. This is closely related to the ideal concept built by the television. Sometimes a television can collapse because the feedback it gives to the public doesn't work. This happens because the public or television viewers as objects are sometimes passive, in the sense that they do not give any reaction to the presentation of television shows. Therefore, program managers or designers must be able to meet the diverse tastes of viewers, so that whatever programs are presented by television stations, 
they must be the best choice results from the many programs that have undergone a selection process and a survey of viewers.

The support of the people of Bandung City and the people of cities in West Java is a supporting factor for the birth and development of PJTV. There are so many programs from private televisions in Indonesia, making regional or local televisions participate in competing to form televisions that are able to provide information for the community and the region. Raising the name of the media is the main goal that PJTV is building today. Feedback from the audience as a supporting factor can be seen from the data collected by PJTV through the results of telephone polling in March 2017, in collaboration with Telkom. Apart from the feedback factor from viewers, other supporting factors are the theme of the program and the broadcast time that is presented for each program. An interesting event theme and the right viewing hours will support the audience or viewers to remain loyal to PJTV. Another supporting factor, namely the presence of advertisements in every event must also be considered, because in the end the presence of advertisements here also helps raise funds for the smoothness and sustainability of the program material both in terms of quality and quantity. The existence of advertisements for television also serves as a means of information about a production item to be known by viewers or the public.

Inhibiting factors that can hinder the development of PJTV so that strategies must be prepared so that managed television continues to exist and become the favorite media of choice for viewers. FaThese offices are: first, technology, technology that is owned is still very limited so that it affects the visual quality of the program material being broadcast. Second, commercially, PJTV must deal with the large number of local television stations and private television stations based in big cities that have relay stations in Bandung, so that in finding advertisements they still encounter obstacles, so for the time being PJTV still relies on the acquisition of local advertisements. Third, the problem of human resources, generally the human resources in PJTV do not have a special television education base.

\section{Conclusion}

1. PJTV shows programs that are dominated by Sundanese culture (70\%), as an effort to preserve and socialize Sundanese culture with the target audience of the people of Bandung City and cities in West Java in general such as Cianjur Regency, Sumedang Regency, Majalengka Regency, and Kuningan Regency.

2. The factors that support the development of PJTV as local regional television based on Sundanese culture are; support from the people of Bandung City and the people of West Java, then various themes of the event which are packaged attractively along with the right viewing hours, as well as the inclusion of advertisements that aim to provide information and help contribute to the smoothness and sustainability of the program material both in terms of quality and quantity.

3. The factors that hinder the development of PJTV in providing attractive and quality shows for viewers are; The first factor is the limited technology that is owned so that it affects the visual quality of the program material being broadcast. The second inhibiting factor is commercial, PJTV has to deal with the large number of local television stations and private television stations based in big cities that have relay stations in Bandung, so that in finding advertisements they still encounter obstacles, so that for the time being PJTV still relies on obtaining local advertisements. The third factor is the problem of human resources, generally the human resources in PJTV do not have a special television education base. 


\section{References}

Andrea, Ardiyana, 2003. Dampak Media Televisi. Tesis. Pekanbaru: Universitas Riau. Avery, Robert. K. 1980. Communication And The Media. New York: Random House.

Bakker, J.W.M.Sj. 1989. Filsafat Kebudayaan Sebuah Pengantar. Yogyakarta: Penerbit Kanisius, BPK Gunung Mulia.

Bill, Rubben. 1996. Communication And Human Behaviour. New York: Free Press.

Cangara, Hafied. 1998. Pengantar Ilmu Komunikasi. Jakarta: PT. Raja Grafindo Persada.

Chaplin. 1975.Dictionary Of Psychology.New York: Dell Publishing Co.

Creswell, John W. 1998. Qualitative Inquiry And Research Design Choosing Among Five Tradition. London: Sage Publication.

Defa, et al. (2020). Development of Visual Media Characteristic of BatakCulture "Dalihan $\mathrm{Na}$ Tolu" for Students in 6th GradeElementary School. Britain International of Humanities and Social Sciences (BIoHS) Journal. P. 757-764

Effendy, Uchjana, Onong. 2000. Ilmu, Teori Dan Filsafat Komunikasi. Bandung: PT Citra Aditya Ba.kti.

Jahi, Amir. 1980. Komunikasi Massa Dan Pembangunan Pedesaan Di Negara Negara Dunia Ketiga. Bandung: PT Gramedia.

Johnson, Doyle, Paul. 1994. Teosi Sosiologi Klasik Dan Modern. Terjemahan Robert Lawang, Jilid I dan II. Jakarta: Gramedia.

Koentjaraningrat. 1990. Pengantar Ilmu Antropologi. Jakarta: PT Rineka Cipta. 1987. Kebudayaan, Mentalitas, dan Pembangunan. Jakarta: PT Gramedia.

Kuntowijoyo. 1987. Budaya Dan Masyarakat. Yogyakarta: PT Tiara Wacana Yogya.

Kuswandi, Wawan. 1996. Komunikasi Massa Sebuah Analisis Media Televisi. Jakarta: PT Rineka Cipta.

Ishadi. 1991. Khalayak Komunikasi Massa. Jakarta. PT Rineka Cipta.

Littlejohn, Stephen. W. 1991. Theories of Human Communications.

MC. Quail, Denis. 1987. Teori Komunikasi Massa. Penterjemah. Agus Dharma. Jakarta: Erlangga.

Mulyana, Deddy. 2012. Metodologi Penelitian Kualitatif. Bandung: PT Remaja Rosdakarya.

1998. Komunikasi Antar Budaya. Bandung: PT Remaja Rosdakarya.

Moleong, Lexy, J. 2000. Metodologi Penelitian Kualitatif. Bandung: PT Remaja Rosdakarya.

Napitu, U., et al. (2020). Challenges and Its Approaches to Bring Integration of Indonesian People. Britain International of Humanities and Social Sciences (BIoHS) Journal. P. 381-391

Parsons, Talcot. 1991. The Social System. New York. USA (Indian edition, 1972): The Macmillian Company.

Rachmat, Jalaludin. 1996. Psikologi Komunikasi. Bandung: PT Rosdakarya.

Reza, Kamal. 2004. Televisi Sebagai Komunikasi dan Pembangunan. Jakarta: Universitas Indonesia.

S>K, Ishadi. 1991. Masyarakat Informasi. Kompas, Juli 1990.

Soemardi, Soelaeman dan Soemarjono, Selo. 1994. Komunikasi Dan Pembangunan Masyarakat. Jakarta: FISUI.

Wahyudi, J.B. 1996. Dasar Dasar Jurnalistik Radio \& Televisi. Jakarta: PT Pustaka Utama Grafiti. 